\title{
MICROFOSSILS ASSOCIATED WITH CHERT CONCRETIONS OUTCROPS IN ASSISTENCIA AND TERESINA FORMATIONS (PARANÁ BASIN).
}

Amanda M. Rios (IC), Fresia Ricardi-Branco (PQ).

\begin{abstract}
The main objective of this research is the study of the Permian fossil record of plantonic life found in chert concretions, associated with layers of carbonate sedimentary rocks outcropping in the municipalities of Santa Rosa do Viterbo and Conchal/SP, belonging to Assistencia and Teresina Formations (Passa Dois Group, Parana Basin). A systematic comparison of the microfossils will be based on morphological and anatomical characters. The good preservation of specimens allow the classification and understanding of the way of life, habitats and taphonomy of the deposits in which they are found. It is worth mentioning that the microfossils present in the Passa Dois Group are still little studied and even more those associated with chert concretions and carbonate rocks of the Permian Paraná Basin.
\end{abstract}

Key words: Assistencia and Teresina Formations, Chert Concretions, Microfossils.

\section{Introduction}

The study of Permian fossil has a valid importance, since this period was characterized by an overall increase in dryness, difficulting the analysis and the study of all forms of life. In order to contribute to the knowledge of that record, this research aims to study the fossil record preserved in chert concretions, associated with layers of outcropping carbonate rocks in the municipalities of Santa Rosa do Viterbo and Conchal. Given the excellent preservation provided by rocky bodies made up of chert, it was possible to recognize, relatively easily, fossils specimens analyzed in the petrographic microscope slides; while for not accurately identified bodies thus we used the SEM (Scanning Electron Microscope), ending the process of characterization of the fossil record found in the search material.

\section{Results and Discussion}

Specimens were characterized by carbonatic material, such as ooids, oncoids, ostracods permineralized by quartz, calcite and chalcedony peloids; microscopic in size; as well as cyanobacteria colonies; fragments of columnar microbial mats (arborescent) and phytoclasts (xylem).

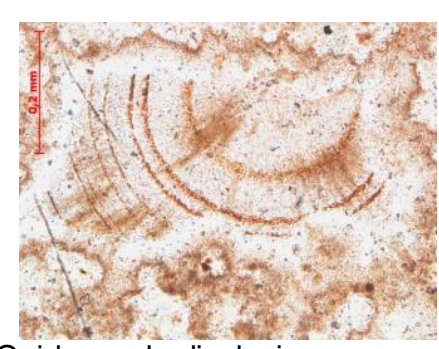

Figure 1. Ooid sample displaying your concentrically.

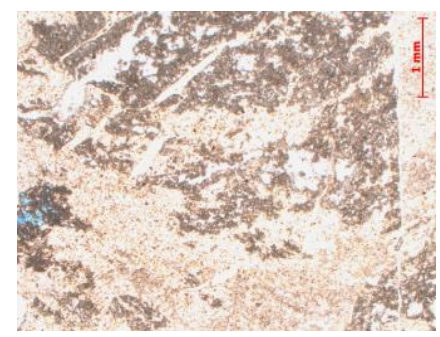

Figure 2. Evidence of Microbial Mats Arborescent.

\section{Conclusions}

All taxa found and previously classified have affinity and have been identified with the help of the literature, however, their presence is unprecedented in outcrops studied here.

\section{Acknowledgement}

Thanks this project direct to the guiding Fresia Ricardi-Branco, the National Research Council and the State University of Campinas.

1 CALÇA, C.P. 2008. Microbiota Fóssil em Sílex da Formação Assistência (Subgrupo Irati, Permiano, Bacia do Paraná) no Estado de São Paulo. Dissertação de Mestrado, Ig-USP, São Paulo. P. 2 66. 